\title{
Yaratıcı Dramanın Kendini Tanıma Düzeyine Etkisi
}

\author{
Hasan Hüseyin Altınova ${ }^{1}$
}

\author{
Elif Gökçearslan Çiftci²
}

\begin{abstract}
$\ddot{O z}$ et
Bu araştırmada, sosyal hizmet bölümünde ögrenim gören öğrencilerin kendilerini ifade etme becerileri üzerinde yaratıcı drama uygulamasının etkisi incelenmiştir. Araştırma, Ankara Üniversitesi Sağlık Bilimleri Fakültesi Sosyal Hizmet Bölümü’nde seçmeli yaratıcı drama dersini alan 24 birinci sınıf ögrencisi ile yapılmıştır. Araştırmada veri toplama aracı olarak öğrencilerin kendilerini tanıttıkları metinler kullanılmıştır. Araştırma, ön test-son test modelinin kullanıldı̆̆ y yarı deneysel bir çalışmadır. Öğrencilere araştırmacılar tarafindan hazırlanan "Yaratıcı Drama Programı", toplam 12 oturum olarak uygulanmıştır. Her bir oturum yaklaşık 180 dakika sürmüştür. Verilerin analizinde, içerik analizi yöntemi kullanılmıştır. Öğrencilerin kendilerini tanıttıkları metinlerin sözcük ve cümle sayımı yapılmış, içerik analizi yoluyla da metinlerden belli kategoriler oluşturulmuştur. Ön test-son test sözcük ve cümle sayımı arasındaki farkı bulabilmek için Wilconson Işaretli Sayılar Testi kullanılmıştır. Elde edilen sonuçlara göre, 12 haftalı yaratıcı drama uygulaması sonucunda ögrencilerin kendilerini tanıtırken cümle ve sözcük sayllarının arttı̆̆l, kendini ifade etme, kendine ait farkındalık oluşturma ve kendini tanıma düzeylerinin geliştiği belirlenmiştir.
\end{abstract}

Anahtar Kelimeler: kendini tanıma, kendini ifade, yaratıcı drama

\section{The Effect of Creative Drama on Self-Knowledge}

\begin{abstract}
In this study, the effect of creative drama on self-expression of the undergraduate social work students is examined. The research was conducted with 24 Ankara University Social Work Junior students who took Creative Drama as an elective course. As a tool for data collection, texts in which students introduce themselves are used. This research is a semi-experimental study where pre-test and post-test models are used. In the scope of the project, 12 session Creative Drama Programme is applied to the students. Each session approximately took 180 minutes. Content analysis was employed as the main analysis method. Word and sentence count was conducted regarding the introduction texts and categories are created through content analysis. In order to find the word and sentence count difference between the pre-tests and post-tests, Wilcoxon Signed-Rank test was employed. According to the results, the number of words and sentences that students use to describe themselves have increased after the 12 week creative drama sessions. Moreover, their level of self-expression, self awareness and self-knowledge skills have improved.
\end{abstract}

Key Words: self-knowledge, self-expression, creative drama

1 Öğr, Gör., Ankara Üniversitesi Sağlık Bilimleri Fakültesi Sosyal Hizmet Bölümü, altinova2012@gmail.com

2 Doç. Dr., Ankara Üniversitesi Sağlık Bilimleri Fakültesi Sosyal Hizmet Bölümü, elifgokcearslan@gmail.com 


\section{Giriş}

Kişiler arasında bilgi, duygu, düşünce, istek ve hayallerin aktarılması anlamına gelen iletişim, toplum içinde yaşayan insanların kendisini doğru, güzel ve etkili bir biçimde anlatabilmesi için gerekli olan bir süreçtir. Sağlıklı bir iletişim kurabilmenin ve karşı tarafı anlayabilmenin ilk koşulu kendini tanımadır (Jack ve Miller 2008; Özcan 2006). Kendini tanıma; duygu ve düşüncelerle ilişki kurma, insanın kendinde olup biten duygusal ve düşünsel süreçlerle ilgili bir anlayışa sahip olması ve duygu ve davranışlarının nedenleri hakkında bir fikre sahip olmasıdır. Kendini tanımak için öncelikle güçlü ve gelişmeye açık yönleri bilmek, duyguları tanımak, bu farkındalığı düşünce ve davranışlara rehber olacak şekilde kullanmak ve kendini açık bir biçimde ifade edebilmek gerekmektedir (Dökmen, 2011).

Kendini tanıma; bir insanın fiziksel özelliklerini, duygularını, düşüncelerini, istek ve gereksinimlerini, güçlü ve zayıf yönlerini, amaç ve değerlerini, yeteneklerini ve becerilerini tanıması, bilmesi ve bunların farkında olmasını ifade eder (Rothman,1999; Üstün, Akgün ve Partlak 2005). Ayrıca kendini tanıma ile insanın kendisiyle, duygu ve düşünceleri ile ilişki kurması, kendisinde olup biten duygusal ve düşünsel süreçlerle ilgili bir anlayışa kavuşması anlatılmaktadır (Cüceloğlu, 1998; Elliott ve Coker, 2008; Silvia, 2002). Kendini tanıma, davranışlarımızı etkileyen kendi düşünce, inanç, duygular, kişisel özellikler, kişisel değerler, alışkanlıklar, ön yargılar, güçlü yönler, zayıflıklar ve psikolojik ihtiyaçların fark edilebilmesidir (Rothman, 1999). Rogers'a (2003) göre kendini tanıma birbiriyle bağlantılı dört temel boyutta gerçekleşir.

1. Psikolojik boyut; insanın duygularını, güdüleyici faktörleri, nelerden etkilendiğini, benlik kavramını, kişiliğini tanımasıdır.

2. Fiziksel boyut; insanın fiziksel durumunu, fiziksel potansiyelini, beden imgesini tanımasıdır.

3. Sosyal boyut; insanın ilişkilerinin ve iletişiminin farkında olmasıdır.

4. Felsefi boyut; insanın yaşam ve ölüme verdiği anlamın, insana ve kendine ilişkin değerlerinin, inançlarinın farkında olmasıdır.

Bireylerin duygu, düşünce ve isteklerini eksiksiz ifade edebilmeleri, anlatma becerilerini ve sözcük dağarcıklarını geliştirebilmelerine bağlıdır (Aykaç, 2013). Düşünceleri, duyguları, tasarıları, istekleri doğru aktarabilmek, geniş bir söz dağarcığına ve dil birikimine sahip olmayı gerektirir. Bu beceriyi kazanamamış bireylerin çevresiyle gerçek anlamda bir iletişim kurması olanaksızdır (Adalı, 2009).

Duyguları ifade etme, sözel ve sözel olmayan elementleri içermektedir (Berry ve Pennebaker, 1993; Kennedy-Moore \& Watson, 2001). Kennedy-Moore ve Watson (2001: 187), duyguları ifade etmeyi gözlenebilen sözel ve sözel olmayan davranışlarla duygusal yaşantıyla iletişim kurulması ya da sembolize edilmesi olarak tanımlamaktadır. Barr ve diğerleri (2008:1068) duyguları ifade etmenin "davranışla ifade etme, duyguları açma, ifade ederek yüzleşme" gibi üç kategoride gerçekleştiğini belirtmektedir. Buna göre duyguları açma, duyguları ifade etmenin bir yönünü oluşturmaktadır.

Aykaç ve İlhan (2011) tarafından yapılan araştırmada deney grubunda uygulanan çocuk edebiyatı metinleriyle kurgulanan yaratıcı drama etkinliklerinin, kontrol grubunda uygulanan öğretmen kılavuz, öğrenci ders ve çalışma kitaplarına dayalı etkinliklere göre öğrencilerin konuşma becerisini geliştirmede daha etkili olduğu sonucuna varmıştır. Pennebaker ve Graybeal'in (2001) üniversite öğrencileri üzerinde gerçekleştirdiği duyguları açma eğitiminin, öğrencilerin iş bulma düzeylerini artırdığı ve sahip oldukları iyilik halini artırdığına yönelik bulgusu, söz konusu araştırma bulgusunu destekler niteliktedir.

Kendini tanıma ve ifade etme becerilerinin uygulamalarla geliştirilmesinde yaratıcı drama etkin bir yöntem olarak kullanılabilir. Yaratıcı dramada kullanılan oyunlar, rol oynamalar, doğaçlamalar ve canlandırmalar, yaşam 
durumlarına bir hazırlıktır ve yazma, konuşma, kendini ifade etme gibi becerilerinin geliştirilmesinde önemli bir yeri vardır. Yaratıcı dramanın en önemli özelliği; bir başkası olmak ve onu oynamaktır. İnsan başkalarını oynarken bir bakıma kendini anlatır. İnsan bir başkasını oynarken önce kendini sonra başkasını anlamaya, keşfetmeye, kavrayabilmeye başlar. Kendini onun yerine koyar. Katılımcılar, rol aldığı bir oyunda canlandırdığ karakterin özelliklerine bürünürken kendini ve insanları farklı açıdan görmeye çalışır. Değişik rolleri alan, farklı kişiliklere bürünen insan, kendini ve çevresini daha kolay tanır. Yaratıcı dramaya katılanlar kurgusal olarak başkasının rolüne girer, roldeki o insanmış gibi davranır ve onun dünyasını anlar. Ancak bunu yaparken aslında bir bakıma kendisini oynar, kendi duygularından yola çıkar ve böylelikle kendi duygularını tanır. Bir rol içinde "ben olsaydım böyle yapardım” demeye başladığında kendisini de tanımaya başlar.

Yaratıcı drama aynı zamanda katılımcının öz güven, karar verme becerilerini geliştirmesine, farklı olay ve durumlarla ilgili deneyim kazanmasına, problemleri yeni bir bakış açısıyla çözmesine, bireyler arasındaki farklılıklara hoş görüyle bakabilmesine, soyut kavramları, olguları somutlaştırmasına yardımcı olur (Adıgüzel, 2010). Yaratıcı drama çalışmaları ile öğrenciler yalnızca öğrenmezler, aynı zamanda toplumsallaşır, kendisine güvenir, kendisiyle birlikte başkalarına saygıyı geliştirir. Bağımsız ve demokratik bir tutum takınır. Yaratıcı drama çalışmaları örgün eğitimin her basamağında, yaygın eğitimde dersler içinde ve bir öğretim yöntemi olarak ve ayrıca başlı başına bir alan olarak yer alabilmektedir (San, 1991).

Kendini tanıma ve kendini ifade etme, yardım edici ilişkilerde önemli becerilerden birisidir. Sosyal hizmet, öğretmenlik, psikolojik danışma gibi mesleklerde büyük önemi olan bu becerilerin geliştirilmesi öncelikle lisans eğitimi sırasında sağlanabilir. Bu mesleklerin eğitimi sırasında kendini tanıma, kendini ifade etme, sözel ve yazınsal anlatım becerilerinin gelişmiş olması beklenmektedir.

\section{Araştırmanın Amacı}

$\mathrm{Bu}$ araştırmanın amacı, sosyal hizmet bölümünde öğrenim gören öğrencilerin kendilerini tanımalarında yaratıcı dramanın etkisini belirlemektir.

\section{Yöntem}

$\mathrm{Bu}$ araştırma, deneme öncesi modellerden “Tek grup ön test-son test modeli” kullanılarak gerçekleştirilmiştir (Karasar, 2007). Araştırmanın bağımsız değişkeni “yaratıcı drama programı”, bağımlı değişkeni de öğrencilerin kendilerini ifade etme düzeyleridir. Araştırmada kullanılan modelin simgesel görünümü Tablo (1)' de gösterilmektedir

Tablo 1. Araştırma Deseni

\begin{tabular}{cccc}
\hline & Ön Testler & Deneysel İșlem & Son Testler \\
\hline \multirow{2}{*}{ Grup } & Ön metin & Yaratıcı drama uygulaması & \multirow{2}{*}{ Son metin } \\
\hline
\end{tabular}

\section{İşlem}

Yaratıcı drama uygulamaları, yaratıcı drama dersinin sorumlu öğretim elemanı tarafından yürütülmüştür. Öğretim elemanı Çağdaş Drama Derneği tarafından verilen yaratıcı drama liderliği belgesine sahiptir. Çalışma, hazırlık- ön test uygulaması, uygulama süreci ve son test-genel değerlendirme olmak üzere üç aşamada gerçekleştirilmiştir. 
Hazırlık-ön test uygulaması: Üniversite öğrencilerine yaratıcı drama ve program hakkında bilgi verilmiş, yapılan çalışmalara katılım teşvik edilmiştir. Ayrıca öğrencilerden beklenilenler açıklanmıştır. Daha sonra her öğrenciye çalışma öncesinde on dakika süre verilerek "Kendinizi Tanıtınız" konulu soru yazılı olarak verilmiştir ve öğrencilerden kendilerini yazılı olarak tanıtmaları beklenmiştir.

Uygulama süreci: Araştırmanın uygulama süreci üçer saatlik 12 oturum biçiminde gerçekleştirilmiştir. Derslerde yaratıcı dramanın aşamaları ısınma, canlandırma ve değerlendirme olarak ele alınmıştır. Ders planları sosyal hizmet öğrencilerinin edinmesi gereken temel beceriler dikkate alınarak hazırlanmıştır. Bu programda; kendini ve duygularını tanıma, anlama, duyguları ifade edebilme, kendine ilişkin farkındalık geliştirme, empati becerilerinin geliştirilmesi hedeflenmiştir. Bu bağlamda yaratıcı dramanın kendini ifade etmeyi geliştirmede bir yöntem olarak kullanılabileceği düşünülmektedir. Bu amaçla, yaratıcı dramada bulunan doğaçlama, rol oynama ve diğer yaratıcı drama teknikleri kullanılmıştır.

Son test uygulaması: Öğrencilere son derste "Kendinizi Tanıtınız” konulu soru yazılı olarak tekrar verilmiştir.

\section{Uygulanan Yaratıcı Drama Programı}

Hazırlanan eğitim programının amacı sosyal hizmet öğrencilerinin kendini tanıma ve tanıtma becerilerini geliştirmektir. Programın temel konu başlıkları ve uygulamalar şu şekildedir:

İlk oturumda, uyulması gereken kurallar oluşturulmuş, grup üyelerinin kendilerini gruba tanıştırması ve gruba katılım amaçlarını anlatmaları istenmiştir. Daha sonra grup üyeleri ve liderin birbirlerini tanıması için isim öğrenme oyunları oynanmıştır. İsmimi kim koydu canlandırmaları yapılmıştır. Değerlendirme aşamasında ise isimlerin anlamları, bize yüklediği roller, sorumluluklar üzerine konuşulmuştur.

İkinci oturum “İletişim Becerileri” başlığında yapılmıştır. Bu oturumun temel amacı öğrencilerin temel iletişim becerilerini geliştirmenin yanında grup içindeki iletişim ve etkileşimi artırmaktır. Ayrıca öğrencilerin kendi iletişim biçimlerini görmeleri amaçlanmıştır. Bu amaçla iletişim etkileşim oyunları, iletişim odaklı rol oyunları oynanmıştır.

Üçüncü oturumda grubun uyum ve güvenini sağlamak için uyum ve güven oyunları oynanmıştır. Güven temalı grup canlandırmaları yapılmıştır.

Dördüncü oturum duygular başlığıyla yapılmıştır. Duyguların önemi, duyguları tanımlamak ve doğru ifade edebilmek bu oturumun genel amacıdır. $\mathrm{Bu}$ amaçla çeşitli duygu yürüyüşleri yapılmış ve karşılıklı duyguların verildiği rol oynama canlandırmaları yapılmıştır.

Beşinci oturum empati başlığıyla yapılımıştır. Empati kurmanın engelleri, Empati düzeyleri bu oturumun genel amacıdır. Bu amaçla gruba değişik insan fotoğrafları gösterilmiş ve bu fotoğraflardaki insanlarda yola çıkarak ikili ve grup doğaçlamaları yapılmıştır.

Altıncı oturum girişkenlik (Pasif, saldırgan ve girişken davranış) başlığıyla yapılmıştır. Girişken davranışlarda bulunma, girişken olmanın önemi, bu oturumun genel amacıdır. Nu amaçla gruba pasif davranış, girişken davranışın olduğu metinler dağıtılmış ve bunlarda yola çıkarak doğaçlamalar yapılmıştır.

Yedinci oturum “Sorun Çözme Yaklaşımı” başlığında yapılmıştır. Bu oturumun temel amacı sorun çözme becerisi geliştirmek ve öğrencilerin kendi sorunları üzerinde düşünmesini sağlamaktır. Bu amaçla oyunların yanı sıra Düğüm Çözme”, "Dokuz Nokta" etkinlikleri yapılmış ve kişilerarası sorunları temel alan canlandırmalar yapılmıştır. 
Sekizinci oturum yaratıcı düşünme becerisini geliştirmek için yapılmıştır. Bu amaçla grup üyelerine ikişer fotoğraf dağıtılmış ve üyelerden bu fotoğraflara bakarak düşünmeleri ve içlerinden fotoğrafların ne zaman ve nerede çekildiği, neyi anlattığı konusunda yorum yapmaları istenmiştir. Sonrasında beşerli gruplar oluşturulmuş ve üyelerden ellerindeki fotoğraflarda neler gördüklerini diğer arkadaşlarına anlatması istenmiş ve her gruptan bir kişi fotoğrafları grup üyelerine bir cümle ile yorumlamıştır. Daha sonra grup lideri tarafından bu fotoğraflarla ilgili olarak sorular sorulmuştur. Grup tekrar yedi gruba ayrılmış ve her gruptan belirli bir kesimi temsil edecek şekilde (aile, medya, akademisyenler, çocuklar, halk, işverenler, elit kesim) on dakika boyunca onların düşüncelerini ve mevcut konuya bakış açısını yansıtan yazı yazmaları istenmiştir. Böylece herkes grupların fikirlerini ifade ederek olaylara bakış açılarını ortaya koymuşlardır.

Dokuzuncu oturum sorgulama, yorumlama ve eleştirel düşünme becerilerini desteklemek amaciyla yapılmıştır. Bu amaçla grup lideri daha önce hazırladığı haber içeriklerini grup üyelerine dağıtmış ve üyelerden haberi 5N1K şeklinde yorumlamalarını istemiştir. Sonra aynı haber kâğıdına sahip olanların bir arada bulunduğu beşerli gruplar oluşturulmuş, haberde yanlış, hatalı ve yanlı bulunan noktaların belirlenmesi, değerlendirilmesi istenmiştir.

Onuncu oturum eleştirel düşünme, alternatif çözüm yolları üretme amacıyla yapılmıştır. Bu amaçla grup, lider tarafından yedi küçük gruba ayrılmış ve yine grup liderinin çalışma öncesinde hazırladığı yedi toplumsal sorun eleştirel düşünme, seçenek oluşturma ve tartışma yollarıyla çözüme kavuşturulmak üzere gruplara dağıtılmıştır. Öncelikle her grup önce kendi içinde sorunu analiz etmiş, mevcut durumun olumlu olumsuz yönlerini çıkarıp hep birlikte çözüm yolu üretmiştir. Daha sonra gruplar sırayla değerlendirmelerini, sonucu ve çözüm önerilerini açıklamışlardır.

On birinci oturumda altı şapka düşünce tekniği üzerine çalışmalar yapılmıştır. Grup lideri tarafından üyelerden sarı, kırmızı, beyaz, siyah, yeşil ve mavi renklerinin kendilerinde neleri çağrıştırdığını renklerin yazılı olduğu kâğıtlara ifade etmeleri istenmiştir. Grup lideri sorular sorarak bu renklerin grup üyelerinin kendilerinde ve diğer üyelerde oluşturduğu etkiyi görmelerine yardım etmiştir.

On ikinci oturumda, geçen 11 oturumun değerlendirmesi, kazanımlar, grup üyelerinin kendinde olan değişimler ve grupta olan değişimler üzerinde konuşularak genel değerlendirme yapılmıştır.

\section{Çalışma Grubu}

Araştırmanın çalışma grubunu Ankara Üniversitesi Sağlık Bilimleri Fakültesi Sosyal Hizmet Bölümü’nde yaratıcı drama dersini seçen birinci sınıföğrencileri oluşturmaktadır. Çalışma grubu 16 kadın, 8 erkek olmak üzere 24 öğrenciden oluşmaktadır. Her bir öğrenciye bir kod verilmiştir. Kodlama sisteminde K, kadın öğrencileri; E erkek öğrencileri; K1Ö birinci kadın katılımcının ilk metinlerini, K1S birinci kadın katılımcının son metinlerini temsil etmektedir. Benzer şekilde E1Ö birinci erkek katılımcının ilk metinlerini, E1S birinci erkek katılımcının son metinlerini temsil etmektedir. Kodlama sisteminde öğrencilerin tanınmaması için isimleri verilmemiştir.

\section{Veri Toplama Yöntemi}

Araştırma nitel desende oluşturulmuş ve yürütülmüştür. Nitel araştırmalarda gözlem, görüşme ve doküman analizi gibi nitel veri toplama yöntemleri kullanılır ve algılar ile olaylar doğal ortamda gerçekçi ve bütüncül bir biçimde ortaya konmaya çalışılır (Yıldırım ve Şimşek, 2005). Nitel araştırmalarda araştırmacı, verileri teker teker okuyarak kodlar ve kategorize eder. Bu elde ettiği kodlara ve kategorilere dayalı olarak araştırma sonuçlarını ortaya koyar (Merriam, 1998: 58). 
Çalışmada veri toplama yöntemi olarak doküman analizi kullanılmıştır. Doküman analizinin birinci aşamasında örneklem grubunda yer alan öğrencilerin yazdıkları ön metinler ve son metinler DOC formatında bilgisayar ortamına aktarılmıştır. Bu aşamada araştırmanın etik boyutu açısından metinlerin asıl sahipleri olan kişi açıkça referans gösterilmeyeceğinden, metinler dosya isimleriyle kodlanmıştır. İkinci aşamada ise bilgisayar ortamına aktarılan metinler kod numarası sırasına dâhilinde çözümlemeleri çalışma kapsamında geliştirilen Tematik Kategoriler Formu aracılıyla yapılmıştır. Tematik Kategoriler Formu (1) düşünce- duygu ifadeleri, (2) kendini tanıtmada dış odaklılık (3) kendini tanıtmada iç odaklılık, (4) öz değerlendirmelerin olup olmadığ1, (5) kendi aile ve sosyal çevresinden bahsetme olmak üzere toplam beş (5) maddeden oluşturulmuştur. Nitel bir çalışmanın içinde veriler nicelleştirilmiş ve frekansları bulunmuş. Nicel veri olarak öğrencilerin kendini tanıttıkları yazılardaki sözcük ve cümle sayılarına bakılmıştır.

\section{Veri Toplama Araci}

Veri toplama aracı olarak öğrencilerin yaratıcı drama dersinin ilk ve son haftasında kendilerini tanıtmak amacıyla yazdıkları metinler kullanılmıştır. Katılımcılara metinlerini yazmak üzere 10 dakika süre verilmiştir.

\section{Verilerin Analizi}

Nicel verilerin analizinde SPSS 17.00 istatistik paket programı kullanılmıştır. Sözcük ve cümle sayılarının cinsiyetler açından karşılaştırılmasında Mann-Whıtney U testinden yararlanılmıştır. Kız ve erkek öğrencilerin kendi içlerinde yaşadıkları değişimin belirlenmesinde ise Wilcoxon İşaretli Sıralar testi kullanılmış, elde edilen sonuçların yorumlanmasında .05 anlamlılık düzeyi dikkate alınmıştır. Nicel verilere birbirine bağımlı örneğin aynı dağılım gösterip göstermediğini belirlemek için kullanılan parametrik olmayan testlerden Wilconson İşaretli Sayılar Testi kullanılmıştır. Verilerin analizinde öğrenciler tarafından doldurulan tüm formlar değerlendirmeye alınmıştır.

Nitel verilerin analizinde, öğrencilerin kendilerini tanıttıkları yazılara içerik analizi yapılmıştır. İçerik analizi sözel, yazılı ve diğer materyallerin nesnel ve sistematik bir şekilde incelenmesine olanak tanıyan bilimsel bir yaklaşımdır (Tavşancıl ve Aslan, 2001). Bilgin'e göre içerik analizi, eldeki yazılı bilgilerin temel içeriklerinin ve içerdikleri mesajların özetlenmesi ve belirtilmesi işlemi olarak da tanımlanmaktadır. İçerik analizi, bir metnin öğelerinin önceden saptanan kategorilere göre sınıflandırılmasına dayanan bir yöntemdir. Kelimeler, cümlecikler, paragraflar ya da tüm belgeler gibi (Gökçe 1992: 100). İçerik analizinin temel amacı, sayıca fazla olan metin yığınında, araştırma sorusu açısından önem arz eden ortak bilgileri tespit etmek ve değerlendirmektir. Kisaca içerik analizi, araştıracağı metinlerin içeriklerinin her yanı ile ve tüm boyutu ile ilgilenmemekte, özellikle ve öncelikle araştırma açısından önemli olduğu varsayılan boyutları üzerine odaklanmaktadır.

İçerik analizinin ilk aşaması olan verilerin kodlanması sürecinde, öncelikle tüm öğrencilerin metinleri bir bütün olarak ele alınmış ve öğrenci kâğıtlarından elde edilen cümle ve kelimeler incelenmiştir. Ardından, elde edilen bilgiler anlamlı bölümlere ayrılmış ve bunların kavramsal olarak ifade ettikleri anlamlar bulunmaya çalışılmıştır. Strauss ve Corbin (1990), üç tür kodlama biçiminden söz etmektedirler: Daha önceden belirlenmiş kavramlara göre yapılan kodlama, verilerden çıkarılan kavramlara göre yapılan kodlama ve genel bir çerçeve içinde yapılan kodlama (Yıldırım ve Şimşek, 2005). Bu araştırmada kodlamayı yaparken verilerden çıkarılan kavramlara göre yapılan kodlama tercih edilmiştir. Kodlama sürecinde araştırmanın kavramsal çerçevesi dikkate alınarak araştırma sorularının dışında kalan veriler kodlanmamıştır.

Daha sonra, ulaşılan veriler defalarca okunmuş ve böylelikle araştırmanın amacı çerçevesinde önemli olan boyutlar saptanmaya çalışılmıştır. Yani, verilerden hareketle tema ve kategoriler oluşturulmuştur. Bu aşamada, bilgiler orijinal formu ve anlamı bozulmadan word dosyası aracılığıyla belirlenen kategoriler altına 
yerleştirilmiştir. Bu şekilde oluşturulan kod listesi, tüm verilerin işlenmesi için kavramsal bir yapı teşkil etmiştir. Kodlar doğrudan verilerden üretildiğinden tümevarımcı bir yol izlenmiştir.

\section{Geçerlik}

Nitel araştırmalarda araştırılan olgu veya olayların sayısal özellikleri değil nitelikleri önemli görüldüğünden, araştırma sonuçlarının doğruluğu yani geçerlik, sonuçların tekrar edilebilirliğinden (güvenirlikten) daha önemlidir (Yıldırım ve Şimşek, 2005).

Nitel araştırmalarda en çok kullanılan veri toplama teknikleri gözlem, görüşme ve/veya yazılı dokümanların incelenmesidir. Bu tekniklerde kullanılan ölçüm aracı araştırmacının kendisi ve sorduğu sorulardır. $\mathrm{Bu}$ nedenle toplanan nitel verilerin geçerlik boyutunu sağlayabilmesi, araştırmacının kendisine ve yönelttiği sorulara bağlıdır. Dolayısıyla geçerliği sağlamak adına bu araştırmada, görüşme ve gözlem formu uzman görüşü alınarak teyit edilmiştir. Ayrıca içerik analizindeki temalar ve kodlar uzman görüşü alınarak düzeltilip geliştirilmiştir (Kaba ve Özdemir Şimşek, 2013; Ataseven, 2012).

Çalışmanın iç geçerliğini sağlamak için: (i) Çalışmada elde edilen veriler, bulgular bölümünde sunulurken söz konusu duruma ilişkin bilgiler ortaya konulduktan sonra yorumlama yoluna gidilmiştir. (ii) Bulguların tutarlılığının sağlanması için kategorileri oluşturan temaların kendi aralarındaki tutarlılığı içsel homojenlik ve dışsal heterojenlik ölçütleri dikkate alınarak değerlendirilmiştir. Çalışmanın dış geçerliğini sağlamak için: (i) Çalışmanın yöntem bölümünde, desen, örneklem, veri toplama aracı, verilerin çözümlenmesi süreçlerindeki işlemlere ayrıntılı olarak yer verilmiştir. (ii) Bilgisayar ortamına aktarılan ön metinler ve son metinler ile kayıtları ve çözümlemeleri ileriki dönemde olası teyide yönelik olarak muhafaza edilecektir.

\section{Güvenirlik}

Nitel araştırmaya temel oluşturan ilkelerden birisi, gerçeklerin bireylere ve içinde bulunulan ortama göre sürekli bir değişme içinde olduğu ve araştırmanın benzer gruplarda tekrarlanmasının aynı sonuçlara ulaşmayı mümkün kılmadığını en baştan kabul etmektir. Güvenirlik boyutunu nitel araştırmalarda sağlamanın yolu yine araştırmacının kendi elindedir. Araştırmacı uygulayacağı stratejilerle, yaptığı nitel çalışmalarda maksimum düzeyde güvenilir veri toplama şansına sahip olabilir (Ataseven, 2012). Bu araştırmada araştırmanın güvenirliği açısından, gözlemcinin aynı zamanda araştırmacı olması, gözlemi etkili yapamaması gibi bir durumu ortadan kaldırmıştır (Kaba ve Özdemir Şimşek, 2013).

Çalışmanın iç güvenirliğini sağlamak için veri analizinde elde edilen çözümlemelerin sunumunda öncelikle yorum yapılmadan direkt verilmiştir. Bu durum, daha sonra yapılacak yorumlar ve açıklamalara temel oluşturmuştur ve aynı çözümlemeye ilişkin tüm bulgulara yer verilmiştir. Veri analizi için kuramsal yapı temel alınarak kategorilerin belirlenmesi sağlanmıştır. Veri analizi sürecinde kodlamaları araştırmacı haricinde başka araştırmacılar tarafından da yapılarak karşılaştırılmıştır. Çalışmanın dış güvenirliğini sağlamak için benzer çalışma yapacak araştırmacılara, çalışma desenlerini kurgularken yardımcı olabilmek amacıyla, çalışmada üzerinde çalışılan durum ve kullanılan yöntemler, çalışmanın ilgili bölümlerinde detayları ile sunulmuştur. Veri toplama ve analizi yöntemleri ile ilgili ayrıntılı açıklamalara yer verilmiştir. 


\section{Bulgular ve Yorum}

$\mathrm{Bu}$ bölümde uyulama öncesi ve sonrasına ilişkin kendini ifade etme becerisine ilişkin bulgulara yer verilmiştir.

\section{Sözcük ve Cümle Sayılarına İlişkin Betimsel İstatiksel Bulgular}

Kendini ifade etme düzeylerini belirlemek için yazılardan elde edilen verilere ilişkin istatistikler Tablo 2'de verilmiştir.

Tablo 2. Sözcük Sayımı İstatistikleri

\begin{tabular}{|c|c|c|c|c|c|c|c|c|}
\hline & \multirow{2}{*}{ Gruplar } & \multirow{2}{*}{ n } & \multicolumn{2}{|c|}{ Ön Uygulama } & \multicolumn{2}{|c|}{ Son Uygulama } & \multicolumn{2}{|c|}{ Fark } \\
\hline & & & $\bar{X}$ & ss & $\bar{X}$ & ss & $\bar{X}$ & ss \\
\hline \multirow{3}{*}{ 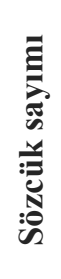 } & Kadın & 16 & 79,06 & 24,91 & 139,68 & 41,03 & 60,62 & 39,21 \\
\hline & Erkek & 8 & 69,50 & 34,38 & 124,25 & 27,29 & 54,75 & 21,81 \\
\hline & Toplam & 24 & 75,87 & 28,03 & 134,54 & 37,15 & 58,66 & 5,16 \\
\hline \multirow{3}{*}{ 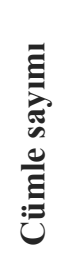 } & Kadın & 16 & 13,68 & 4,88 & 18,37 & 5,94 & 4,68 & 4,82 \\
\hline & Erkek & 8 & 13,87 & 7,01 & 20,00 & 5,70 & 6,13 & 5,13 \\
\hline & Toplam & 24 & 13,75 & 5,52 & 18,91 & 5,79 & 5,16 & 4,86 \\
\hline
\end{tabular}

Tablo 2'de görüldüğü gibi kendini ifade etmek için yazılan yazılarda öğrenciler uygulama öncesi 75,87 sözcük ortalaması ile kendilerini tanıtmışlardır. Çalışma sonucunda ise 134,54 sözcük ortalamasına ulaşılmıştır. Katılımcıların ön test ve son testte kullandıkları sözcükler arasındaki farklılığa bakıldığında 58,66'lık sözcük artışı olduğu görülmektedir. Kadın öğrencilerin kullandığı sözcük sayısında erkek öğrencilere göre daha fazla artış olduğu görülmektedir.

Tablo 2'de görüldügü gibi kendini ifade etmek için yazılan yazılarda öğrenciler uygulama öncesi 13,75 cümle ortalaması ile kendilerini tanıtmışlardır. Çalışma sonucunda ise 18,91 cümle ortalamasına ulaşmıştır. Cümlelerin son test ve ön test arasındaki farklılıklarına bakıldığında 5,16 'lık sözcük artışı görülmektedir. Sözcük sayımının tersine, erkek öğrenciler kadın öğrencilere göre sözcük sayısında daha fazla artış göstermiştir.

\section{Sözcük ve Cümle Sayılarının Karşılaştırılmasına İlişkin Bulgular}

Yapılan yaratıcı drama çalışmasının öğrencilerin kendilerini tanıtmada kullandıkları sözcük ve cümle sayısını arttırdığı görülmektedir. Bu farklılıkların istatistiksel olarak anlamlı olup olmadığını belirlemek için öğrencilerin ön test ve son test uygulamalarından elde ettikleri puanların kendi içlerindeki değişimi incelenmiştir. Bu değişimin belirlenmesinde Wilcoxon İşaretli Sıralar testinden faydalanılmıştır. 
Tablo 3. Cümle ve Sözcük Sayımı Ön-Son Test Puanlarının Wilconson Işaretli Sayılar Testi Sonuçları

\begin{tabular}{|c|c|c|c|c|c|c|}
\hline Ölçme & Değişim Yönü & $\mathbf{N}$ & $\begin{array}{c}\text { Suralamalar } \\
\text { Ortalaması }\end{array}$ & $\begin{array}{c}\text { Siralamalar } \\
\text { Toplamı }\end{array}$ & $\mathbf{Z}$ & $\mathbf{p}$ \\
\hline \multirow{4}{*}{ Sözcük sayımı } & Negatif Değer & $0^{\mathrm{a}}$ &, 00 &, 00 & \multirow{4}{*}{$-4,286^{\mathrm{a}}$} & \multirow{4}{*}{, 000} \\
\hline & Pozitif Değer & $24^{\mathrm{b}}$ & 12,50 & 300,00 & & \\
\hline & Eşit & $0^{\mathrm{c}}$ & & & & \\
\hline & Toplam & 24 & & & & \\
\hline \multirow{4}{*}{ Cümle Sayımı } & Negatif Değer & $2^{\mathrm{d}}$ & 3,50 & 7,00 & \multirow{4}{*}{$-3,775^{\mathrm{a}}$} & \multirow{4}{*}{000} \\
\hline & Pozitif Değer & $19^{\mathrm{e}}$ & 11,79 & 224,00 & & \\
\hline & Eşit & $3^{\mathrm{f}}$ & & & & \\
\hline & Toplam & 24 & & & & \\
\hline
\end{tabular}

Tablo 3'te görüldüğü gibi ön uygulamada 75,87 olan sözcük ortalaması, uygulama sonrasında 134,54'e çıkmıştır. Yapılan Wilconson İşaretli Sayılar Testi sonucunda öğrencilerin ön test ve son test sözcük sayımı ortalamaları arasında son test lehine istatistiksel olarak anlamlı fark bulunmuştur $(p<0,05)$. Bu durum yaratıcı drama çalışması sonrasında öğrencilerin kendini ifade ederken daha çok sözcük kullandığını göstermektedir.

Tablo 3’te görüldügü gibi ön uygulamada 13,87 olan cümle sayısı ortalamas1, uygulama sonrasında 19,12'ye çıkmıştır. Yapılan Wilconson İşaretli Sayılar Testi sonucunda öğrencilerin ön test ve son test cümle sayısı ortalamaları arasında son test lehine istatistiksel olarak anlamlı fark bulunmuştur $(\mathrm{p}<0,05)$. Bu durum yaratıcı drama çalışmasının öğrencilerin kendini ifade ederken daha çok sözcük kullandığını göstermektedir.

\section{Sözcük ve Cümle Sayılarının Cinsiyete İlişkin Bulgular}

Yapılan yaratıcı drama çalışmasının hem kadın hem de erkek öğrencilerin kendilerini tanıtmada kullandıkları sözcük ve cümle sayısını arttırdığı görülmektedir. Bu farklılıkların istatistiksel olarak anlamlı olup olmadığını belirlemek için öğrencilerin ön metin ve son metin uygulamalarından elde ettikleri puanların kendi içlerindeki değişimi incelenmiştir. Bu değişimin belirlenmesinde Wilcoxon İşaretli Sıralar testinden faydalanılmıştır. 
Tablo 4. Cinsiyete Göre Sözcük ve Cümle Sayımı Puanlarının Wilconson Iş̧aretli Sayılar Testi Sonuçları

\begin{tabular}{|c|c|c|c|c|c|c|c|}
\hline Cinsiyet & Ölçme & Değişim Yönü & $\mathbf{N}$ & $\begin{array}{c}\text { Suralamalar } \\
\text { Ortalaması }\end{array}$ & $\begin{array}{c}\text { Siralamalar } \\
\text { Toplamı }\end{array}$ & $\mathbf{Z}$ & $\mathbf{p}$ \\
\hline \multirow{8}{*}{$\begin{array}{l}\text { Kadın } \\
\text { Öğrenciler }\end{array}$} & \multirow{4}{*}{$\begin{array}{l}\text { Sözcük } \\
\text { Sayımı }\end{array}$} & Negatif Değer & $0^{\mathrm{a}}$ &, 00 &, 00 & \multirow{4}{*}{$-3,516^{a}$} & \multirow{4}{*}{, 000} \\
\hline & & Pozitif Değer & $16^{\mathrm{b}}$ & 8,50 & 136,00 & & \\
\hline & & Eşit & $0^{\mathrm{c}}$ & & & & \\
\hline & & Toplam & 16 & & & & \\
\hline & \multirow{4}{*}{$\begin{array}{l}\text { Cümle } \\
\text { Sayımı }\end{array}$} & Negatif Değer & $2^{\mathrm{d}}$ & 3,25 & 6,50 & \multirow{4}{*}{$-3,042^{a}$} & \multirow{4}{*}{, 002} \\
\hline & & Pozitif Değer & $13^{\mathrm{e}}$ & 8,73 & 113,50 & & \\
\hline & & Eşit & $1^{\mathrm{f}}$ & & & & \\
\hline & & Toplam & 16 & & & & \\
\hline \multirow{8}{*}{$\begin{array}{l}\text { Erkek } \\
\text { Öğrenciler }\end{array}$} & \multirow{4}{*}{$\begin{array}{l}\text { Sözcük } \\
\text { Sayımı }\end{array}$} & Negatif Değer & $0^{\mathrm{a}}$ &, 00 &, 00 & \multirow{4}{*}{$-2,521^{a}$} & \multirow{4}{*}{, 012} \\
\hline & & Pozitif Değer & $8^{b}$ & 4,50 & 36,00 & & \\
\hline & & Eşit & $0^{\mathrm{c}}$ & & & & \\
\hline & & Toplam & 8 & & & & \\
\hline & \multirow{4}{*}{$\begin{array}{l}\text { Cümle } \\
\text { Sayımı }\end{array}$} & Negatif Değer & $0^{\mathrm{d}}$ &, 00 &, 00 & \multirow{4}{*}{$-2,207^{a}$} & \multirow{4}{*}{, 027} \\
\hline & & Pozitif Değer & $6^{\mathrm{e}}$ & 3,50 & 21,00 & & \\
\hline & & Eşit & $2^{\mathrm{f}}$ & & & & \\
\hline & & Toplam & 8 & & & & \\
\hline
\end{tabular}

Tablo 4'te görüldügüü gibi drama uygulaması öncesi kadınlarda 79,06 olan sözcük ortalaması, uygulama sonrasında 139,68'e çıkmış, erkeklerde de uygulama öncesi 69,50 olan sözcük ortalaması uygulama sonrasında 124,25 'e çıkmıştır. Tablo 2'de görüldüğü gibi uygulama öncesinde kadınlarda 13,68 olan cümle ortalaması uygulama sonrasında 18,37 'e çıkmış, erkeklerde de uygulama öncesi 13,87 olan sözcük ortalaması uygulama sonrasında 20,00'ye çıkmıştır.

Tablo 4'de görüldüğü gibi de kadın öğrencilerin hepsi son test ön test farkına göre sözcük sayımında pozitif değer almış, cümle sayımında iki öğrenci negatif değer, bir öğrenci aynı değeri almıştır. Erkek öğrencilerin hepsi sözcük sayımında pozitif değer almış, cümle sayımında da iki öğrenci eşit değer almıştır.

Yapılan Wilconson İşaretli Sayılar Testi sonucu hem kadınların kendi içinde hem erkeklerin kendi içinde 
ön test ve son test sözcük sayımı ve cümle sayımı ortalamaları arasında son test lehine istatistiksel olarak anlamlı fark olduğunu göstermektedir $(\mathrm{p}<0,05)$. Bu sonuçlara göre hem kadınların hem erkeklerin sözcük ve cümle sayısının yaratıcı drama uygulamasından sonra geliştiği söylenebilir.

\section{Sözcük ve Cümle Sayılarının Cinsiyet Karşılaştırmasına İlişkin Bulgular}

Sözcük ve cümle sayılarının ön metinlerde, son metinlerde ve son metin-ön metin sayısı farkında sözcük ve cümle sayısında kız ve erkek öğrenciler arasında değişip değişmediğini belirlemek için nonparametrik test olan Mann-Whitney U yapılmıştır.

Tablo 5. Cümle ve Sözcük Sayımı Puanlarının Cinsiyetler Arası Mann-Whitney U Testi Sonuçları

\begin{tabular}{|c|c|c|c|c|c|c|}
\hline Ölçüm & Cinsiyet & $\mathbf{n}$ & $\bar{X}$ & ss & $\mathbf{z}$ & $\mathbf{p}$ \\
\hline \multirow{3}{*}{$\begin{array}{l}\text { Sözcük Sayımı } \\
\text { Öntest }\end{array}$} & Kadın & 16 & 79,06 & 24,91 & \multirow[b]{2}{*}{,- 643} & \multirow[b]{2}{*}{, 520} \\
\hline & Erkek & 8 & 69,50 & 34,38 & & \\
\hline & Toplam & 24 & 75,87 & 28,03 & \multirow{4}{*}{,- 889} & \multirow{4}{*}{,374 } \\
\hline \multirow{3}{*}{$\begin{array}{l}\text { Sözcük Sayımı } \\
\text { Sontest }\end{array}$} & Kadın & 16 & 139,68 & 41,03 & & \\
\hline & Erkek & 8 & 124,25 & 27,29 & & \\
\hline & Toplam & 24 & 134,54 & 37,15 & & \\
\hline \multirow{3}{*}{$\begin{array}{l}\text { Sözcük Sayımı } \\
\text { Fark }\end{array}$} & Kadın & 16 & 60,62 & 39,21 & \multirow{2}{*}{,- 061} & \multirow{2}{*}{,951 } \\
\hline & Erkek & 8 & 54,75 & 21,815 & & \\
\hline & Toplam & 24 & 58,66 & 5,16 & \multirow{4}{*}{,- 492} & \multirow{4}{*}{,623 } \\
\hline \multirow{3}{*}{$\begin{array}{l}\text { Cümle Sayımı } \\
\text { Öntest }\end{array}$} & Kadın & 16 & 13,687 & 4,88 & & \\
\hline & Erkek & 8 & 13,87 & 7,019 & & \\
\hline & Toplam & 24 & 13,75 & 5,52 & & \\
\hline \multirow{3}{*}{$\begin{array}{l}\text { Cümle Sayımı } \\
\text { Sontest }\end{array}$} & Kadın & 16 & 18,37 & 5,94 & \multirow[b]{2}{*}{,- 891} & \multirow[b]{2}{*}{,373 } \\
\hline & Erkek & 8 & 20,00 & 5,70 & & \\
\hline & Toplam & 24 & 18,91 & 5,79 & \multirow{4}{*}{,- 644} & \multirow{4}{*}{, 519} \\
\hline \multirow{3}{*}{$\begin{array}{l}\text { Cümle Sayımı } \\
\text { Fark }\end{array}$} & Kadın & 16 & 4,68 & 4,82 & & \\
\hline & Erkek & 8 & 6,12 & 5,13 & & \\
\hline & Toplam & 24 & 5,16 & 4,86 & & \\
\hline
\end{tabular}

Tablo 5'de görüldüğü gibi yapılan Mann-Whitney U Testi sonucu kadın ve erkek öğrencilerin öntest sonucuna göre cümle ve sözcük sayımına göre farklılaşmadıkları belirlenmiştir $(\mathrm{P}>0.05)$ 
Tablo 5'de görüldüğü gibi yapılan Mann-Whitney U Testi sonucu kadın ve erkek öğrencilerin sontest sonucuna göre cümle ve sözcük sayımına göre farklılaşmadıkları belirlenmiştir $(\mathrm{P}>0.05)$

Tablo 5'de görüldüğ̈̈ gibi uygulama öncesi ve sonrası kadınların sözcük sayımı fark1 ortalamas1 60,62'dir. Erkeklerde ise bu fark 54,75 olmuştur. Bu durum sözcük sayımı bakımından farklar arası farkın kadınlar ile erkekler arasında bir farklaşmanın olmadığını göstermektedir $(\mathrm{p}>0,05)$.

Tablo 5'de görüldüğü gibi ön uygulamada öncesi ve sonrası kadınların cümle sayımı fark ortalaması 4,68 olmuştur. Erkeklerde ise bu fark 6,13 olmuştur. Bu durum cümle sayımı bakımından farklar arası farkın kadınlar ile erkekler arasında bir farklaşmanın olmadığını göstermektedir $(\mathrm{p}>0,05)$.

\section{5. İçerik Analizi Bulguları}

Bu bölümde öğrencilerin yazdığı metinler kategorilere ayrılarak çözümlenecek ve yorumlanacaktır. Bu kategoriler (1) duygu ifadeleri, (2) kendini tanıtmada iç odaklılık (3) kendini tanıtmada dış odaklılık (4) öz değerlendirmelerin olup olmadığı (5) kendi aile ve sosyal çevresinden bahsetme şeklin olmak üzere beş kategoride yapılmıştır. Her kategoride ifade sayısı yazarın açıklamaları ve öğrencilerin görüşlerine kendi ifadeleriyle yer verilecektir. Araştırmada katılımcıların metinlerinden birebir alıntılar kullanılmıştır. Öğrenciler belirtilen kategorileri toplam ön metinlerde 338, son metinlerde ise 541 ifade kullanarak cevaplandırmışlardır. Tablo 6' da bu ifadelerin beş genel kategoriye göre dağılımları ve yüzdeleri verilmiştir.

Tablo 6. İ̧erik Analizi Sonucu Oluşan Kategorilerin Sayı ve Yüzde Dağılımları

\begin{tabular}{lcccc}
\hline \multirow{2}{*}{ İfadeler } & \multicolumn{2}{c}{ Ön metin } & \multicolumn{2}{c}{ Son metin } \\
\cline { 2 - 5 } & Sayı & $\mathbf{\%}$ & Sayı & \% \\
\hline Duygu ifadeleri & 103 & 30,5 & 202 & 37,3 \\
Dış odaklılık ifadeleri & 55 & 16,3 & 62 & 11,5 \\
İç odaklılık ifadeleri & 42 & 12,4 & 76 & 14,0 \\
Öz değerlendirme ifadeleri & 76 & 22,5 & 108 & 20,0 \\
Aile ve sosyal çevre ifedeleri & 62 & 18,3 & 93 & 17,2 \\
Toplam & 338 & 100 & 541 & 100 \\
\hline
\end{tabular}

Tablo 6 incelendiğinde, öğrencilerin en çok duygu ifadeleri kullandıkları görülmektedir. Bu kategoride yer alan ifadeler, toplamda ulaşılan ifadelere oranı ön metinde $103(\% 30,5)$, son metinde ise $202(\% 37,3)$ 'dir. Daha sonra sırasıyla öz değerlendirme ön metinde $76(\% 22,5)$, iken son metinde $108(\% 20,0)$ dir. Aile ve sosyal çevreden bahsetme ön metinde 76 (\% 18,3), son metinde 108 (\% 17,2) olmuştur. Dış odaklılık ön metinde 55 $(\% 16,3)$ iken son metinde $62(\% 11,5)$ olmuştur. İç odaklılık ise ön metinde $42(\% 12,4)$ iken son metinde $76(\%$ 14,0) olmuştur. Bu sonuçlar, son metinlerde duygu ifadelerinin ve iç odaklılığın daha çok arttı̆̆ını göstermektedir.

\section{a. Duygu İfadelerine İlişkin Bulgular}

Kendini açıklama becerileri, üzüntü ve mutluluk gibi hissedilenlerin açılanması, düşüncelerin açıklanması, övgüleri kabul etme, kendisi hakkında olumlu söz söyleme. Kendini tanımanın önemli bir boyutu kendi duygu ve düşüncelerini tanımadan geçmektedir. Öğrencilerin kendilerini tanıttıkları yazıların içerik 
analizinin birinci teması duygu ve düşünce ifadeleridir. Öğrencilerin yazdığı ön metinler ve son metinler incelendiğinde, ön metinde 103 duygu ifadesi kullanılırken ikinci metinde 202 duygu ifadesi kullanıldı̆̆ mıştır. Yüzde olarak da öğrencilerin son metinlerde daha çok duygu ifadesi kullandıkları gözlenmiştir. Aşağıda öğrencilerin yazdıkları metinlerden örnekler verilmiştir.

Sevmeyi seviyorum. Çoğu şeyi umursamadan rahat bir insanım. K.3.Ö

Genelde kendimi mutlu hissederim. K.6.Ö

Önyargılarım çok fazladır. Genelde yanlışlarımı bilirim. Çok çabuk özlerim, çok çabuk sıkılırım. Küçük şeylerle de mutlu olmasinı bilirim. K.3.Ö

Kolay sinirlenen ve kolay siniri geçen bir yapım var. Insanlar arasında hemen fark edilmeyi dikkat çekmeyi severim. Insanlara çabuk güvenirim. Ve bu özelliğim başıma her zaman dert olur. Dost edinme konusunda da hep başarısı oldum. Yine de kendimi hep şansl ve mutlu ederim. Umudumu kaybetmem bana göre umudunu kaybeden içindeki öfkeye sartlır. E.4.Ö

Hayatta kötü olaylarla pek yüzleşmemişimdir. Verdiğim kararlardan pek pişman olmamışımdır. K.16.Ö

Kızdığım birisini kolay affetmem. Çok inatçıyım. Hayatta hep inatçı olmam dolayıslyla eleştirilmişimdir. E.6.Ö Adımı seviyorum. Ama işlek olmadı̆̆ını düsünüyorum. İlerde olurda torunlarım olursa .....(isim yazmış) nene mi diyecek? Hoş olmaz diye düşünüyorum. K.12.̈̈

Bir insanı ya severim ya da ondan nefret ederim. K.3.S

En kötü özelliğim aniden sinirlenmelerimdir. Biraz da bunu engellemek için katılmak istedim. K.9.Ö

Ablamın olması iyi bir şey. Hele de bu abla maaşlyysa daha da iyi birşey. K12.S

Annem merhamet fiçısı. Babam ciddiyet ve kural deposu. Kardeşimi zorla okutuyoruz. Erkek çocuğu olduğu içi biraz rahat büyüdü. Ailemden bahsediyorum. Çünkü ben demek onlar demek, onlar demek ben demek. Kendimi bildim bileli cidi ve soğukkanlıyım. K.12.S

Genel olarak hayatımdan memnunum. Huzurlu ve mutlu birisiyimdir. K.6.S

Ara final stresiyle doluyum nedense. E.6.S

Planı severim ama plansız birine âşı olmayı becerecek kadar da aptalım. E.4.S

Kızdığım birisini kolay affetmem. Çok inatçıyım. Hayatta hep inatçı olmam dolayısıyla eleştirilmişimdir. K.2.Ö

Hayatta en çok “Annemi ve Babamı” seviyorum. İkisini de çok özlüyorum ve bana verdikleri her şey için onlara çok teşekkür ediyorum. K.2.S

Insanlardan mekânlardan bir süre sonra sıkllyyorum. Bu huyumdan nefret ediyorum. Kendimle ilgili en sinir olduğum şey insanlara fazla değer veriyorum. E.7.S

Birilerinin sorunları benim en büyük problemim oluyor. Bunu umarım meslek hayatımda yapmam eğer yaparsam iyi bir sosyal hizmet uzmanı olamayacağımı düşünüyorum. Insanlarla ilgili en sinir olduğum şey ise birilerini tanımadan onlar hakkında yargılarda bulunmamaları. Bu zihniyetin değişmesi gerektiğini düşünüyorum. E.1.S Hayatta denemediğim hiçbir şey kalsın istemem. Dolu dolu yaşamalıyım. K.14.S

Birine sinirlendiğimde onu öldürebilirim sanırım ama öfkem çabuk geçer kimsenin zarar görmesini istemem en nefret ettiklerim de dâhil. K.13.S 
Kendini tanımanın önemli bir boyutu, kendi duygu ve düşüncelerini tanımadan geçmektedir. Öğrencilerin kendilerini tanıttıkları yazılarda içerik analizinin birinci teması olan duygu ifadelerine bakıldı ğında, ilk metinlerde daha az duygu ifadesi kullanırken ikinci metinlerde daha çok duygu ifadesi yerini aldığı gözlenmektedir. Ayrıca ilk metinde daha çok düşünce cümleleri, ikinci metinde ise daha çok duygu cümleleri yer almaktadır. Öğrencilerin ikinci metinlerde kendilerini daha rahat ve içten ifade ettikleri gözlenmiştir. Bunların yanında metinlerde “:)"(güler yüz) gibi simgeler kullanılmıştır. Bu durum, duygularının yoğunluğunu ve daha çok ifade etme isteklerinden kaynaklanıyor olabilir. Yazınsal olarak beden dilini kullanamadığımızda ve bazı kelimeler yetersiz kaldığında bu ifadeleri kullanırız. İkinci metinlerde sıklıkla bu ifadelerin yer alması, duygusal yoğunluklarının bir göstergesi olabilir.

Duygu ifadelerin yoğun olması, yaratıcı drama dersi sırasında katılımcılara gösterilen demokratik tutum ve kendini ifade etmede önyargısız olmaktan da kaynaklanabilir. Ayrıca uygulamalar sırasında öğrenciler pek çok role girip çıkmış ve pek çok duygu durumuna girmişlerdir. Bu da onların kendilerini daha kolay ifade etmesini kolaylaştırmıştır. Bunun yanında ders kapsamında öğrenciler çeşitli durumlar kurgulamışlardır. Böylelikle belli durumda kendilerini nasıl hissettiklerini gözlemlemiş olabilecekleri düşünülmektedir.

\section{b. Dış Odaklılık İfadelerine İlişkin Bulgular}

Kendini tanımanın önemli bir boyutu da dış odaklılıktır. Bireyler iç ve dış odağa sahip olup olmamalarına göre, farklı kişisel özelliklere sahip olurlar. Dış odaklılıkta başkalarından söz etme başkalarından etkilenme söz konusudur. Dış odaklılıkta kendinin dışındaki faktörlerden söz etme ve ilişkilendirme, kendini çevreleyen sosyal dünyadan söz etme vardır. Öğrencilerin yazdığı ön metinler ve son metinler incelendiğinde ön metinde 55 ikinci metinde 62 dış odaklılık ifadesi kullanılmıştır. Bu değerler ön testle son test arasında birbirine yakındır. Aşağıda öğrencilerin yazdıkları metinlerden örnekler verilmiştir.

Ankara'ya bir türlü alışamadım gitti. Şehir bana çok soğuk geliyor hiç ilgi çekici değil. K..15.Ö

Ilk tercihimdi ve bölüme birinci olarak girdim. Eksik taraflarım var ama mesleki bilgi ve becerilerimle, zamanla oluşan tecrübelerle bunu yapabileceğimi düşünüyorum. K.11.Ö

Dostluk benim için çok önemlidir. Hayatımdaki insanlar değiş̧ken değildir. Seçimlerimde dikkatli olmaya özen gösteririm. E.8. O

Her nedense Ankara'yı bir türlü sevemedim ama Ankara'nın çok sevdiğim iki yeri var bunlar: AŞTİ ve Havaalanı çünkü bu yerler beni Ankara'dan uzaklaştırtyor. K.10.S

Yazı yazmayı ve ödev yapmayı okulu ilk başladığım yıldan beri hiç sevmedim ve yapmadım. İlkokulda her ödev kontrolünde dayak yediğimi hala hatırlıyorum. Bu çocuk okumaz denirdi de şimdi üniversite 1. Sinıf öğrencisiyim okul biter mi bilmiyorum. K.12.S

Dış odaklı bireyler kendilerinden çok söz edememektedir. Genellikle duygularını açmada daha yetersizdirler dolayısıyla dış çevreye ve başka kişiler yönelirler.

\section{c. İç Odaklılık ifadelerine İlişkin Bulgular}

Kendini tanımanın bir boyutu da iç odakl11ıktır. İç odaklılıkta kendi duygu dünyasına dönme, duygusunu yaşama, kendinden söz etme, kendi kabiliyetlerini söyleme vardır. Öğrencilerin yazdığı ön metinler ve son metinler incelendiğinde ön metinde 42, ikinci metinde 76 dış odaklılık ifadesi kullanılmıştır. Yüzde olarak da öğrencilerin son metinlerde daha iç odaklılık ifadesi kullandıkları gözlenmiştir. Aşağıda öğrencilerin yazdıkları metinlerden örnekler verilmiştir. 
Her zaman tembel bir ögrrenciydim. Isşime karışanlara kızarım. E.Ö.7

Genel olarak sakin bir kişilik yapısında olsam da sanırım Karadenizli olmamdan da kaynaklanan bir anda sinirlenip bir anda normale dönme huyum var. Bazen olaylara mantıksal açıdan yaklaşamam benim sorunlarımdan biri. E.Ö.6

Insanlara çok kolay güvenmem aynı şekilde çok kolay arkadaşlık da kurmam, sirf bu yüzden çevremde fazla insan bulamazsiniz. K.14.Ö

Ankara okumak için güzel ama yaşamak için sevmedim. K.5.S

Sinirli olduğumda da hiçbir şey benim sinirimi alamaz. E.6.S

Annem ile babam ayrı. En büyük ablam babamla yaşlyor ben ikisine de gidiyorum. Kardeşim annemle yaşlyor. K.11.S

Küçüklüğümden beri hayalini kurduğum yerde miyim? Haylr. Zaten ne istediğime hiçbir zaman tam karar veremedim. Çoğu zaman aklımdan birçok şey geçtiği için işlerinden birini seçip konuşmakta zorlandım. K.9.S

İç odaklı bireyler kendilerinden daha çok söz etmektedir. Duygularını açmada daha isteklidir, kendi yeterliliklerini söylemekten çekinmezler. Son testte iç odaklı sözcüklerin artması yaratıcı dramanın kişinin kendimi tanıması kendine güveni arttırması motivasyon sağlaması, gruba lidere ve kendine güven geliştirmesi ile yakından ilgilidir.

\section{ç. Özdeğerlendirme İfadelerine İliş̧kin Bulgular}

Özdeğerlendirme, bir bakıma belli bir konuda bireyin kendi kendisini değerlendirmesidir. Özdeğerlendirme, öğrencilerin kendilerini keşfetmelerine, güçlü ve zayıf yönlerini tanımalarına yardımcı olur. Öğrencilerin yazdığı ön metinler ve son metinler incelendiğinde ön metinde 76 ikinci metinde 108 öz değerlendirme ifadesi kullanılmıştır. Öğrencilerin son metinlerde daha çok öz değerlendirmede ifadesi kullandıkları gözlenmiştir. Dolayısıyla bazı öğrenciler ilk metinlerde olmayan öz değerlendirmelerini ikinci metinde yaptıkları gözlenmektedir. Aşağıda öğrencilerin yazdıkları metinlerden örnekler verilmiştir.

Kibirli değil soğukkanliyım K.13.Ö

Kendimi bildim bileli ciddi ve soğukkanlıyım. Yeni yeni aşmaya başladım birkaç mesafeyi. K.5.Ö

İnsanlara çabuk güvenirim. Ve bu özelliğim başıma her zaman dert olur. K.6.Ö

Dost edinme konusunda da hep başarisız oldum. K.10.̈̈

Yarın hayatımda olmasını istemediğim, bana zarardan başka bir şeyi olmayan hayatımı zorlaştıran kendime güvenimi, inancımı ve saygımı tükettiren biriyle ilişkimi devam ettirmekteki amacı da hala anlamış değilim. E.3.S

Insanlara fazla şans verdiğime inanıyorum. Ama kızdığım birisini kolay affetmem. K.2.S

Kinci olduğumu ve bana yapılanları da unutmadı̆̆ımı kabul ediyorum. E.1.S

Pozitif bir insanımdır. Tanıştığım kişilere önyargılı olarak yaklaşmam. K.11.S.

En kötü özelliğim aniden sinirlenmelerimdir. E.3.S

Öğrencilerin yazdıkları metinlerden öne çıkan en önemli nokta, kendilerine ilişkin daha kolay ve içten özdeğerlendirmede bulunduklarıdır. Bu metinler dikkate alındığında, öğrencilerle yapılan çalışmaların kendini değerlendirme açısından önemli olduğu söylenebilir 


\section{d. Aile ve Sosyal Çevre İfadelerine İlişkin Bulgular}

İnsan sosyal bir varlık olma özelliği ile diğer insanlarla etkileşim içinde yaşama ihtiyacındadır. Hemen hemen herkes bir aileye ve sosyal çevreye sahiptir. Öğrencilerin yazdığı ön metinler ve son metinler incelendiğinde ön metinde 62 ikinci metinde 93 aile ve sosyal çevre ifadesi kullanılmıştır. Öğrencilerin son metinlerde daha çok ifadesi kullandıkları gözlenmiştir. Dolayısıyla bazı öğrenciler ilk metinlerde olmayan öz değerlendirmelerini ikinci metinde yaptıkları gözlenmektedir. Aşağıda öğrencilerin yazdıkları metinlerden örnekler verilmiştir.

Annem merhamet fiçısl. Babam ciddiyet ve kural deposu. Kardeşimi zorla okutuyoruz. Erkek çocuğu olduğu içi biraz rahat büyüdü. K.4.Ö

Hayatta en çok "Annemi ve Babamı" seviyorum. İkisini de çok özlüyorum ve bana verdikleri her şey için onlara çok teşekkür ediyorum. K.12.Ö

Buraya Manisa'dan geldim. K.1.Ö

Ankara'yı hiç sevmedim. Bölümümden memnunum ama okuldan memnun değilim. E.2.S

Ankara'da okumak hayalimdi. Ama buraya geldiğim için biraz pişmanlık duydum. Çünkü bu şehir hiç bana göre değil. K.8.S

Aile ve sosyal çevre ifadeleri ile ilgili öğrenci metinleri incelendiğinde; yaratıcı drama yönteminin öğrencilerin aile ve sosyal çevre ifadelerini kullanma üzerinde önemli bir role sahip olduğu görülmektedir. Yaratıc1 dramanın özünü oluşturan doğaçlama, rol oynama gibi tekniklerin etkin olarak kullanılması, öğrencilerin sürece etkin olarak katılmalarına olanak sağlamasının yanında, öğrencilerin grupla çalışma ve etkileşimi sayesinde sürekli olarak sosyal rollerini, arkadaş grubu içinde çalışma, başkalarıla rahat iletişim kurma becerilerini olumlu biçimde geliştirdiği söylenebilir. Böylelikle kendilerini tanıtırken aile ve sosyal çevreden bahsetme ihtiyacı duymuş olabilirler.

\section{Tartışma ve Sonuç}

Araştırmada elde edilen bulgular, yaratıcı dramanın üniversite öğrencilerinin kendilerini tanıtırken cümle ve sözcük sayılarının arttırdığını ve kendilerini ifade etme becerilerini geliştirdiğini göstermektedir. Kendini tanıma ve tanıtmaya yönelik eğitim alan üniversite öğrencilerinin son metinlerinde daha fazla sözcük ve cümle kullanmaları kendilerini rahat, güvenli bir ortamda bulunmaları, başkaları tarafından anlaşılan bireyler olmaları bakımından önemli bir yordayıcı olarak düşünülebilir.

Kişiler kendilerini ancak rahat ve güvenli hissettikleri ortamlarda ifade edebiliriler. Tehdit edici, kınayıcı bir ortam bireyi savunucu olmaya iter. Bu durumda duyguların dile getirilmesi güçleşir. Buna karş1lık bireylere rahat olabilecekleri bir ortam sağlandığında, kişilerin kendilerini anlatabilmeleri, duygularını açabilmeleri daha da kolaylaşır. Çalışmanın başlangıcında kişilerin hem kendilerine hem de gruba ve çevrelerine güven duyması daha zor olurken süreç içinde bu duygu gelişme gösterir. Böylelikle kişiler kendilerini daha kolay ifade etme şansı bulurlar.

Aynı zamanda grup içinde yapılan geri bildirimler bireylerin kendi kişiliklerinin farkına varmalarına yardımcı olmaktadır. Başkarı tarafından nasıl algılandıklarını görmek, tanımadıkaları bazı yönlerini tanımalarına yardımcı olabilmektedir. Öğrenciler kendilerini ve duygularını tanıma başladıkça daha spontan ve daha çok kendileri olabilmeyi başarabilmektedir.

Yaratıcı dramanın yapıldı̆̆ Öğrenciler mekânda yere serilen halıların üstünde ve minderlerin üstünde yan yana oturarak, istediklerinde birbirlerine dokunarak etkileşime geçmişlerdir. $\mathrm{Bu}$ da onlarda bir rahatlama duygusu yaratmıştır. 
Öğrencilerin gereksinim duydukları bir başka husus da birbirleriyle daha yakın ilişkiler kurabilmek, birlikte bazı etkinliklerde bulunabilmek ve yaşantılarını paylaşabilmektir. İlişkilerinin ne kadar yüzeysel olduğu, birbirlerini ne kadar az tanıdıkları ve birbirlerine ne kadar az güvendikleri ilk oturumlarda dile getirilirken, sonraki oturumlarda birbirleriyle ilişkileri gelişmiş ayrıca katılımcılar birlikte etkinlikler yapmaya başlamışlardır. Grup içinde konuşabilmek, kendini ifade edebilmek önemli bir sorun olarak ön plana çıkarken sonraki oturumlarda hem konuşma süreleri uzamış hem de yaptıkları doğaçlamarın süresi artmıştır.

Bir başka konu da lider ile öğrenciler arasındaki ilişkiler ile ilgilidir. Lider aynı zamanda öğrencilerin farklı derslerine de girmekte ve farklı görevleri üstenmektedir. Dolayısıyla bu roller öğrenci ile lider arasında ilişkileri etkileyebilmektedir. Ancak üstlenilen farklı rolller öğrencileri engellememiştir. Lider, her zaman o grubun bir üyesi olarak kabul edilmiştir.

Yaratıcı drama oturumları sırasında duygularını ve düşüncelerini içten bir şekilde paylaşan birey, bu duyguları hissetmenin olumsuz bir etkisinin olmadığının, bu duyguları hissetmenin normal bir durum olduğunun farkına varmış olabilir. Bu rahatlama, öğrencilerin özgüvenini ve olumlu kendilik algısını geliştirmiş olabilir. Bu da son metinde daha çok sözcük ile cümle kullanmalarına ve kendilerini daha rahat anlatmalarına neden olmuş olabilir. Ayrıca yaratıcı drama oturumlarında önemli bir konu da katılımcının diğer grup üyelerine, çalışma mekânına ve lidere güven duygusunun geliştirilmesidir. Dolayısıyla oturumlarda güven duygusuna yönelik çalışmalar yapılır. Lidere ve diğer grup üyelerine güven duyan, kendisinin emniyette olduğunu düşünen birey kendisi hakkında daha çok bilgiyi paylaşabilir.

Araştırmadan elde edilen sonuçlar ışı̆̆ında; sosyal hizmet, öğretmenlik, psikolojik danışma gibi insanla çalışan mesleklerin eğitiminde yaratıcı drama dersinin olması ve yaratıcı dramanın uygulanabilirlik düzeyi arttırılması önerilmektedir.

\section{Kaynakça}

Adal1, O. (2009). Anlamak ve Anlatmak. İstanbul: Pan Yayıncılık.

Adıgüzel, H. Ö. (2010). Eğitimde Yaratıı Drama. Ankara: Naturel Yayınları.

Aykaç, M.(2011). Türkçe öğretiminde çocuk edebiyatı metinleriyle kurgulanan yaratıcı drama etkinliklerinin anlatma becerilerine etkisi. Yayımlanmamış doktora tezi, Ankara: Ankara Üniversitesi Eğitim Bilimleri Enstitüsü.

Ataseven, B.(2012). Nitel bilimsel araştırmalarda veri kalitesinin önemi, Marmara Üniversitesi İiB Dergisi, 33 (2), 543-564

Barr, L. K., Kahn, J. H. ve Schneider, W. J. (2008). Individual differences in emotion expression: hierarchical structure and relations with psychological distress, Journal of Social and Clinical Psychology, 27, No. 10,1045-1077.

Berry, D.S. ve Pennebaker, J.W. (1993). Nonverbal and verbal emotional expression and health. Psychotherapy And Psychosomatics, 59, 11-19.

Bilgin, N. (2006). Sosyal Bilimlerde İçerik Analizi: Teknikler ve Örnek Çalışmalar. Ankara: Siyasal Kitabevi.

Corbin, J. M. \& Strauss, A. C. (2007). Basics Of Qualitative Research: Techniques And Procedures For Developing Grounded Theory. Thousand Oaks, CA: Sage Publication.

Cüceloğlu D (1998). Yeniden İnsan İnsana. İstanbul: Remzi Kitabevi.

Dökmen,Ü. (2010). İletişim Çatışmaları ve Empati. İstanbul: Remzi Kitabevi

Elliott, I, Coker, S. (2008). Independent self-construal, self-reflection, and self-rumination: a path model for predicting happiness, Australian Journal of Psychology, 60 (3):127-134.

Gökçe, O. (2006). İçerik Analizi Kuramsal ve Pratik Bilgiler. Ankara: Siyasal Kitabevi

Jack, K, Miller, E. (2008). Exploring self-awareness in mental health practice. Mental Health Practice, 12 (3):31-35. 
Kaba, H. ve Özdemir Şimşek, P.(2013). İlköğretim bölümü yüksek lisans öğrencilerinin fen ve teknoloji öğretiminde yarat1c1 drama yönteminin uygulanılmasına ilişkin görüşleri. Erişim tarihi: 086.01.2014. http://kongre.nigde.edu.tr /xufbmek/ dosyalar/tam_metin/pdf/2485-30_05_2012-22_52_27.pdf

Karasar, N. (2007). Bilimsel Araştırma Yöntemi: Kavramlar, Ilkeler, Teknikler. Ankara: Nobel Yayın Dağıtım.

Kennedy-Moore, E. \& Watson, J.C. (2001). How and when emotional express help? Review of General Psychology, 5 (3), $187-212$.

Merriam, S. (1998). Qualitative Research and Case Study Applications in Education. San Francisco: Jossey-Bass.

Özcan, A.(2006). Hemşire-Hasta İlişkisi ve İletişim. Ankara: Sistem Ofset

Pennebaker, J.W. \& Graybeal, A. (2001). Patterns of natural language use: disclosure, personality and social integration. Current Directions in Psychological Science, 10 (3), 90-93.

Rogers C.R. (2003). Etkileşim Grupları. Ankara: Ege Matbaacılık.

Rothman, J.C. (1999). The Self-Awareness Workbook for Social Workers. Allyn and Bacon,

San, İ. (1991). Eğitimde yaratıcı drama. Ankara Üniversitesi Eğitim Bilimleri Fakültesi Dergisi, 23, 2.

Silvia, P.J. (2002). Self-awareness and emotional intensity. Cognition And Emotion, 16 (2): 195-216.

Tavşancıl, E. ve Arslan, A. E. (2001). Sözel, Yazılı ve Diğer Materyaller İçin İçerik Analizi ve Uygulama Örnekleri. İstanbul: Epsilon Yayinevi

Üstün B, Akgün E, Partlak, N. (2005). Hemşirelikte İletişim Becerileri Öğretimi. İzmir: Okullar Yayınevi.

Yıldırım, A. ve Şimşek, H. (2005). Sosyal Bilimlerde Nitel Araştırma Yöntemleri. Ankara: Seçkin Yayıncılık. 


\title{
The Effect of Creative Drama on Self-Knowledge
}

\author{
Hasan Hüseyin Altınova ${ }^{3}$
}

\section{Elif Gökçearslan Çiftci ${ }^{4}$}

\section{Extended Abstract}

Self-knowledge is forming a relationship with emotions and thoughts, a person's having an understanding about the emotional and intellectual processes going on within himself/herself and having an opinion about the reasons of their emotions and behaviors. Self-knowledge means a person's knowing his/her physical properties, emotions, thougths,wishes and demands, strengths and weaknesses, aims and values, skills and abilities and their being aware of these. Self-knowledge takes place in four dimensions that are interrelated. 1. Psychological dimension is a person's getting familiar with their emotions, motivating factors, what they are affected by, the concept of self, and their personality. 2. Physical dimension is a person's knowing their physical condition, physical potential, and image of body. 3. Social dimension is a person's being aware of their relationships and communication. 4. Philosophical dimension is a person's being aware of the meaning they attribute to life and death, their values of related to themselves, and their beliefs.

Creative drama can be used as an effective method in developing the skills of self-knowledge and selfexpression through implementations. The plays, acting, improvization and animations are preparations towards a living status and they have an important place in developing skills such as writing, speaking and self-expression. The most important characteristics of creative drama is being another one and depicting him/her. In a way, people expresses themselves while depicting others. When people depict others, they start to understand first themselves and then the others. They put themselves in place of those others. While participants take on the traits of the characters they depict in a play, they try to see themselves and people from a different angle. People who take on different roles and assume different personalities more easily recognizes themselves and their surroundings. Those who take part in creative drama take on the role of another person in a fictional way, act as if they were that person and understand his/her world. However, while doing this they in a sense act themselves, set off from their emotions and thus get to know their own emotions. When they start saying "If I was in that role I would do like this", they also start to get familiar with themselves as well.

The purpose of this study is to determine the influence of creative drama on how the students studying in the department of social service get to know themselves.

This study was conducted using the "single group pretest-posttest model", one of the pre-experimental models (Karasar, 2007). The independent variable of the study is "creative drama program" while the dependent variable is the level of students' self-expression. The study was carried out in three phases, namely preparationpretest, the implementation process, and posttest-general evaluation.

The implementation period of the study was 12 three-hoour-long lessons. The steps of creative drama were dealt with as warm-up, animation and evaluation during the lessons. The study group consisted of freshman students who elected creative drama lesson in Ankara University Faculty of Health Sciences, the Department of Social Services. There were 24 students in the group (16 female and 8 male students). The texts that the students

3 Lecturer, Ankara University, Faculty of Health Sciences

4 Assoc. Prof. Ankara University, Faculty of Health Sciences 
had written to introduce themselves in the first and the last weeks of creative drama lesson were used as the data collection tool. The participants were given 10 minutes so that they could write their texts.

The study was designed and carried out in a qualitative pattern. Document analysis was used as the data collection method. The data in a qualitative study were quantified and their frequencies were found. The numbers of words and sentences in the introduction texts of students were examined as the quantitative data. The Thematic Cathegories Form consisted of five items as (1) thought-emotion expressions, (2) outer centeredness in getting to know self, (3) inner centeredness in getting to know self, (4) whether there are self-assessments, (5) and mentioning about one's own family and social neighborhood.

The students introduced themselves with an average of 75.87 words in the introduction texts they had written prior to the implementation. At the end of the study, on the other hand, they reached an average of 134.54 words. When the difference between the words students used in the pretest and the posttest is examined, it is seen that there was an increase in the words by 58.66 words. Moreover, there was a bigger growth in the number of words that female students used than that used by males.

It is seen that students mostly used the expressions of emotion. The ratio of the expressions in this cathegory to the expressions in total is $103(30.5 \%)$ in the pretext and $202(37.3 \%)$ in the final text. After this, self-assessment is $76(22.5 \%)$ in the pretext while it is $108(20.0 \%)$ in the final text. Mentioning about one's own family and social neighborhood is $76(18.3 \%)$ in the pretext while it is $108(17.2 \%)$ in the final text. Outer centeredness is $55(16.3 \%)$ in the pretext while it is $62(11.5 \%)$ in the final text. Finally, inner centeredness is 42 $(12.4 \%)$ in the pretext while it is $76(14.0 \%)$ in the final text.

The findings of the study denote that creative drama increases the numbers of words and sentences used by university students while introducing themselves and improves their skills of self-expression.

The fact that university students receiving training towards getting to know and introducing themselves use more words and sentences in the final text might be considered as an important precursor of being in a comfortable and secure environment and being individuals understood by others. 